\title{
Komunikační výchova a integrace poznatků v kontextu Rámcového vzdělávacího programu pro základní vzdělávání, oborových didaktik a př́pravy učitelů
}

\section{Milan Polák}

\begin{abstract}
Abstrakt
Na základě analýzy vývoje názorů v oblasti komunikační výchovy a integrace poznatků po r. 1989 autor pojmenovává některé tendence ve vzdělávání na základní škole vycházející ze současných kurikulárních dokumentů a týkající se oborových didaktik všech vzdělávacích oborů. $V$ závěru se autor pokusil zformulovat oblasti a problémy, jež bude třeba řešit $v$ náplni oborových didaktik a v př́pravě budoucích učitelů zejména na pedagogických fakultách.
\end{abstract}

Klíčová slova: komunikační výchova, integrace poznatků, vzdělávací program, Rámcový vzdělávací program pro základní vzdělávání, vzdělávací obor český jazyk a literatura, didaktika českého jazyka, oborová didaktika, spolupráce, př́prava a vzdělávání učitelů.

\section{Abstract}

Based on the analysis of opinion development in the field of communication education and integration of knowledge after 1989, the author entitles some tendencies in education at elementary school based on current curriculum documents and concerning the 
didactics of all educational disciplines. In conclusion, the author tries to describe areas and formulate their problems which one should be dealt with in the field of didactics, as well as in the proces of teachers training, especially at Faculties of Education.

Keywords: Communication Education, Integration of Knowledge, Framework Education, Programme for Elementary Education, Didactics of the Czech Language, Cooperation, Teacher Training and Education.

\section{Komunikační výchova a integrace poznatků v nových podmínkách a souvislostech}

Veřejné změny v České republice po r. 1989 s sebou zcela logicky přinesly také změny ve vzdělávání. Uvolnění v oblasti politické mělo za následek zbavení škol ideologického balastu a také postupnou decentralizaci; školy získávají právní subjektivitu a tím také značnou míru autonomie. V oblasti vzdělávání se objevují nové názorové tendence, ty se zcela zákonitě promítají také do pojetí vyučování českého jazyka.

Znovu ožívají spory o podobu jazykového vyučování a zejména o úlohu mluvnice (gramatiky) při naplňování cílů jazykového vyučování, jak je formuloval již v 19. století G. A. Lindner:

- cíl praktický (rozumět projevům a vyjadřovat se),

- cíl formální (prostřednictvím jazyka myslet),

- cíl materiální (prostřednictvím jazyka sdělovat vědomosti).

Tyto cíle respektují všichni jazykovědci a didaktici, rozdílně se ovšem dívají na jejich pořadí, tedy jejich prioritu. Zjednodušeně potom hovoříme o agramatickém a gramatickém pojetí jazykového vyučování. Je třeba připomenout, že se tyto diskuse týkají dřivější obecné školy a dnešního prvního stupně základní školy a zejména prvého cíle, tedy rozvoje komunikačních schopností žáků. S první výraznou kritikou dosavadního pojetí vyučování českého jazyka přichází O. Hausenblas (1992) v publikaci Vrátíme smysl hodinám češtiny? Jako základní cíl výuky v českém jazyce jsou zde vytyčeny komunikační dovednosti a schopnosti žáka, ty mají být rozvíjeny pod vedením učitele v komunikačních situacích. Zvládnutí gramatického systému je až druhotné a nemusí jej zvládnout všichni žáci. Je zde tedy zpochybněna nezastupitelná úloha gramatického učiva zejména při plnění komunikačního cíle výuky mateřského jazyka a jeho praktického zvládnutí.

Jiní odborníci ale vidí úlohu mluvnice v jazykovém vyučování jako zásadní:„Osvojení spisovného jazyka se může založit jen na mluvnici. Komunikační zřetel je jí podřízen, není určující" (Hauser, Kneselová, \& Ondrášková, 1994, s. 10). Ve stejné době se také objevují snahy o integraci komunikační a systémové jazykové výuky (Čechová, 1993), při definování úlohy gramatiky pro rozvíjení komunikačních schopností žáků dospí- 
vá tatáž autorka ve svém díle Čeština a jejívyučování ke kompromisu: „Cíl kognitivní ovládnutí jazykového systému - je ve vztahu k cíli komunikačnímu cílem podřizeným, avšak podmiňuje jeho splnění v tom smyslu, že poznání stavby jazyka je do jisté míry podmínkou úspěšného spisovného funkčního komunikování" (Čechová, 1998, s. 10). Spojení komunikační výchova se začíná objevovat v souvislosti se slohovým vyučováním a členěním v učebnicích českého jazyka (slohová a komunikační výchova).

Různorodost názorů na komunikační výchovu a integraci poznatků se také promítla po r. 1989 do podoby nových vzdělávacích programů, ze kterých si základní školy mohly vybírat. Poslední centrální osnovy pro základní školy v roce 1991 tak postupně nahrazují vzdělávací programy Obecná škola (1996), Základní škola (1996) a Národní škola (1997), které se svým pojetím uvedené problematiky liší.

Obecná škola (1996) formulovala jako základní princip vzdělávání výchovu k občanství, integrační osou všech předmětů se proto stává občanská výchova. V oblasti vyučování českého jazyka se poprvé hovoři o komunikační výchově, a to zejména ve spojitosti se slohovým vyučováním. Autoři programu Národní škola (1997) nabízeli oproti předchozím dokumentům ještě širší možnosti integrace: předměty jsou propojovány do bloků, v tzv. nadstavbové části najdeme celou řadu volitelných předmětů, jež nejsou zaměřeny pouze na kognitivní oblast a mají integrační charakter (dramatická výchova, dějepisné a zeměpisné praktikum aj.). Většina škol se ovšem přiklonila k programu Základní škola (1996), jenž se podobal svým pojetím vyučování koncepci před rokem 1989. Ve všech programech došlo k celkovému snížení časové dotace pro předmět český jazyk na celé základní škole, zatímco rozsah učiva a důraz na ně zůstal především v programu Základní škola zachován (podrobněji Polák, 2002).

Hlouběji se problematikou integrace jazykového vyučování a komunikační výchovy zabývala například Jana Svobodová, jež poukazuje na nutnost integrace všech složek předmětu český jazyka a hovoří v této souvislosti o komplexnosti přístupu při výuce českého jazyka (Svobodová, 2002).

Na práce J. Svobodové navazuje v posledním desetiletí R. Metelková Svobodová, která zkoumá ve svých publikacích Čtenářská gramotnost z lingvodidaktického hlediska (Metelková, 2008) a Čtenářská gramotnost na 1. stupni ZŠ z pohledu vzdělávacího oboru Český jazyk a literatura (Metelková \& Švrčková, 2010) vyučování českého jazyka zejména v souvislosti se čtenářskou gramotností

V posledně jmenované publikaci poukazuje autorka mimo jiné na kritérium komplexnosti při hodnocení učebnic, kromě integrace složek vzdělávacího oboru český jazyk považuje za zásadní také integraci poznatků z dalších vzdělávacích oborů a průrezových témat.

Na základě integrace jednotlivých předmětů se tedy komunikační výchova (a také čtenářská gramotnost) stává záležitostí všech učitelů. V takto širokém a komplexním pojetí definuje komunikační výchovu ve své publikaci Od jazyka ke komunikaci (2005) Karel Šebesta; mezi složky komunikační výchovy zařazuje čtení, psaní, mluvení a naslouchání a jako samostatnou složku mediální výchovu. 
V tomto období vychází také publikace Integrace na základní škole (Podroužek, 2002), zabývající se tímto tématem z různých pohledů a přístupů. Autor se zaměřuje zejména na integrované vyučování - to je chápáno tak, že se snažíme o řešení nějakého problému (či poznání tématu) z různých hledisek jednotlivých vědních oborů, poprípadě o vytvoření nového syntetického předmětu, který by uplatňoval využití mezipředmětových vztahů v obsahu učiva, hovoříme tedy o integrované výuce, kterou autor definuje jako „....spojení učiva jednotlivých učebních předmětů nebo kognitivně blízkých vzdělávacích oblastí v jeden celek s důrazem na komplexnost a globálnost poznávání, kde se uplatňuje řada mezipředmětových vztahů" (Podroužek, 2005, s. 11). Objasňuje mimo jiné koncipování učiva podle různých principů a poukazuje také na toto téma v historickém kontextu.

Právě tento pohled na danou problematiku ukazuje komunikační výchovu v mnohem širších souvislostech a z něj také vychází filozofie rámcových vzdělávacích programů.

\section{Charakteristika Rámcového vzdělávacího programu pro základní vzdělávání}

Ve školním roce 2007/2008 byla na základních školách v České republice uskutečněna první etapa reformy vzdělávání, jež se postupně dotkla také škol středních. Školy vycházející z Rámcového vzdělávacího programu pro základní vzdělávání od tohoto školního roku učí podle vlastních školních vzdělávacích programů. Při jeho tvorbě museli učitelé vycházet ze základních principů nových kurikulárních dokumentů, mezi něž patří právě komunikační výchova a integrace poznatků. Z analýzy Rámcového vzdělávacího programu pro základní vzdělávání (dále jen RVPZV) mimo jiné vyplývá:

1. Na rozdíl od předchozích vzdělávacích dokumentů vymezuje RVPZV již v úvodu výstupní požadavky, tj. vyjadřuje, k jakým výsledkům má vzdělávání dospět. Těmi jsou obecné kompetence, jež mají nadpředmětový (nově nadoborový) charakter (viz dále).

2. Učitelům jsou dávány $\mathrm{k}$ dispozici různé formy integrování obsahu vyučování (využití alternativních metod výuky a informačních technologií, metod kooperativního učení, problémového a projektového vyučování apod.).

3. Mezi priority RVPZV jsou zařazeny dovednosti komunikace a kooperace žáků (část $A$, Východiska, pojetí a charakteristika základního vzdělávání v RVP ZV).

4. Je kladen důraz na výchovu samostatného myšlení žáků.

5. Obecné kompetence žáků jsou zaměřeny na učení, řešení problémů, komunikaci a pracovní činnosti a spolupráci.

6. Všechny cíle jsou vytyčeny a dále realizovány v jednotlivýchvzdělávacích oblastech, jež v sobě zahrnují příbuzné vzdělávací obory (dříve vyučovací předměty). Například 
vzdělávací oblast Jazyk a jazyková komunikace obsahuje vzdělávací obory Český jazyk a literatura, Cizí jazyk a Další cizí jazyk, vzdělávací oblast Člověk a společnost vzdělávací obory Dějepis a Výchovu k občanství.

7. Ve všech vzdělávacích cílech najdeme prvky komunikační výchovy - vzdělávání směřuje např́iklad k tomu, aby žák získal základy tvořivého myšlení, dovedl logicky uvažovat a řešit problémy, dále zvládl základy všestranné a účinné komunikace atd.

8. Rozvoji komunikační výchovy a integraci poznatků napomáhají tzv. průřezová témata, ta mají být realizována ve všech vyučovacích oborech (například Výchova k myšlenív evropských a globálních souvislostech,Mediální výchova aj.).

9. Ústřední myšlenkou RVPZV se tak stává integrace poznatků a komunikační výchova v nejširším slova smyslu (Polák, 2016).

Protože by se tyto tendence měly promítnout také do oblasti oborových didaktik a do prípravy budoucích učitelů, zaměříme na ně pozornost v další části příspěvku.

\section{Komunikační výchova a integrace poznatků v kontextu oborových didaktik a prípravy budoucích učitelů}

Komunikace a komunikační výchova v nejširším slova smyslu se tak stává záležitostí všech vzdělávacích oborů a tedy i jejich učitelů. Ti by měli být také schopni propojovat, tedy integrovat poznatky ze svých vzdělávacích oborů především prostřednictvím průřezových témat a využívat přitom rozličné metody kooperativního učení (napríklad projektovou metodu) a také metody kritického myšlení. $V$ souvislosti s tím by se měl měnit také obsah didaktik jednotlivých vzdělávacích oborů a v návaznosti na to i profil absolventů vysokých škol připravujících budoucí učitele. Ti by tedy měli být vybaveni zcela novými poznatky a dovednostmi nejen z oblasti svých oborových didaktik, ale také disciplín obecně didaktických. $V$ tomto směru je ale zapotřebí realizovat řadu opatření:

- Implementovat do obsahu oborových didaktik (zejména českého jazyka) nové metody a formy práce podporující cíle kurikulárních dokumentů.

- Zavádět do studijních oborů v prípravě budoucích učitelů nové předměty. $\mathrm{Na}$ PdF UP v Olomouci jsou to například předměty Aktivizační metody ve vyučování českého jazyka a literatury, Problematika př́pravy na hodiny českého jazyka se zaměřením na integraci vzdělávacích oborů apod.

- Podporovat spolupráci oborových didaktiků sloužící k rozvíjení průřezových kompetencí v oblasti komunikační výchovy a integrace poznatků. Tato koordinace by měla být realizována ve dvou rovinách. 
První je interní spolupráce oborových didaktiků v rámci jedné vysoké školy (fakulty).

Na Pedagogické fakultě UP Olomouc má tuto podobu:

Středisko praxí PdF UP v Olomouci organizuje pravidelná setkání oborových didaktiků, ta slouží k informacím z oblasti organizace praxe a dále k seznamování s novými trendy v oblasti jednotlivých oborových didaktik a s náplní seminářư z obecné didaktiky, jež předcházejí výuce oborových didaktik.

Na jednotlivých pracovištích PdF UP jsou zadávány kvalifikační práce, jež jsou zaměřeny na integraci poznatků napříč oborovými didaktikami, rozvoj komunikačních schopností žáků atd. v souladu s požadavky pedagogické praxe.

Pracoviště fakulty spolupracují při realizaci projektů zaměřených na uvedenou problematiku. Oboroví didaktici všech oborů by měli být také ve stálém kontaktu s učiteli těchto oborů ve svém regionu. Na Katedře českého jazyka a literatury PdF UP jsou každoročně pořádána již dvacet let setkání s učiteli českého jazyka, kteří vedou studenty na pedagogické praxe, a dalšími zájemci z řad pedagogů. Na nich jsou učitelé formou pracovních dílen a přednášek seznamováni s novými trendy v oblasti vzdělávání

Stejně tak je ovšem nutná i externí spolupráce oborových didaktiků z vysokých škol připravujících budoucí učitele, ta může mít různou podobu. Dále uvádíme některé možnosti a př́klady spolupráce oborových didaktiků českého jazyka, které se v nedávné minulosti uskutečnily a osvědčily:

Od r. 2014 jsou dvakrát ročně realizována střídavě na Moravě a v Čechách celostátní setkání didaktikư českého jazyka, na nichž jsou řešeny aktuální problémy daného oboru, v případě českého jazyka to byla v poslední době např́iklad forma a obsah státní maturitní zkoušky.

Společně jsou realizovány projekty zaměřené na oblast komunikační výchovy. Jako prríklad takové aktivity uvádíme projekt Príprava a realizace výukových materiálu pro podporu komunikační výchovy a mediální výchovy RVP ZV ve výuce českého jazyka a literatury na základních školách a víceletých gymnáziích (hlavní řešitel Mgr. Miloš MIčoch, Ph.D., 2011 2013). Do tohoto projektu se zapojila řada didaktiků a odborníků z PdF UP v Olomouci, ale také z Ostravské univerzity a Univerzity v Plzni. Na tvorbě a ověřování pracovních listů z této oblasti se podílely desítky učitelů základních škol a gymnázií z Moravy i Čech. Výstupy z projektu (například pracovní listy a metodika k nim) jsou volně př́istupné zejména pro pedagogickou veřejnost na metodickém portálu projektu Komunikační výchova a jsou hojně využívány.

\section{Závěr}

Jak vyplývá z našeho pojednání, pojetí komunikační výchovy prošlo zejména v posledních dvaceti letech vývojem od činností spojovaných zejména se slohovým vyučováním až po princip uplatňovaný ve všech vzdělávacích oblastech a oborech obsažených 
v RVP ZV. Právě komunikační výchova a integrace poznatků z jednotlivých vzdělávacích oborů se staly v souladu s cíli RVP ZV jeho hlavními principy. Aby se ale podařilo záměry vytyčené tímto dokumentem realizovat, je nutné, aby se promítly také do oborových didaktik všech vzdělávacích oborů a zejména do vzdělávání budoucích učitelů. Pro naplnění cílů vzdělávání bude třeba $v$ této souvislosti splnit řadu dalších podmínek a kroků, z nichž některé jsme zmínili v našem příspěvku.

\section{Seznam použité literatury}

Čechová, M. (1993). O potřebě integrace komunikační a systémové jazykové výuky. Český jazyk a literatura. 44 (7-8), s. 158-162.

Čechová, M. \& Styblík, J. (1998). Čeština a její vyučování. Praha: SPN.

Hausenblas, O. (1992). Vrátíme smysl hodinám češtiny? Zbuzany: vydáno vl. nákladem.

Hauser, P., Kneselová, H. \& Ondrášková, K. (1994). Didaktika českého jazyka, díl l. Část obecná. Brno: Vydavatelství MU.

Metelková Svobodová R. (2008). Čtenářská gramotnost z lingvodidaktického hlediska. Ostrava: Ostravská univerzita.

Metelková Svobodová R. \& Švrčková, M. (2010). Čtenářská gramotnost na 1. stupni ZŠ z pohledu vzdělávacího oboru český jazyk a literatura. Ostrava: Ostravská univerzita.

Podroužek, L. (2002). Integrovaná výuka na základní škole. Plzeň: Fraus.

Polák, M. (2002). Učitel českého jazyka a současná základní škola. Olomouc: Univerzita Palackého v Olomouci.

Polák, M. (2016). Komunikační výchova a integrace poznatků jako prostředky podpory čtenářské gramotnosti. In Řeřichová, V. Úroveň čtenářských strategií patnáctiletých žáků na konci základního vzdělávání. s. 9-17. Olomouc: Univerzita Palackého v Olomouci.

Svobodová, J. (2002). Počátky komunikační výchovy mateřštiny. In Inovácia. Štrbské Pleso: Združenie Orava.

Šebesta, K. (2005). Od jazyka ke komunikaci. Praha: Karolinum.

\section{Předpisy a dokumenty}

Další rozvoj československé výchovně vzdělávací soustavy II. (1976). Praha: SPN.

Rámcový vzdělávací program pro základní vzdělávání. (2013). Praha: MŠMT.

Dostupné z http://www.msmt.cz/vzdelavani/zakladni-vzdelavani/upraveny-ramcovy-vzdelavaci-program-pro-zakladni-vzdelavani

Učební osnovy základní školy. (1991). Praha: Fortuna.

Vzdělávací program Národní škola. (1997). Praha: SPN.

Vzdělávací program Obecná škola. (1996). Praha: Portál.

Vzdělávací program Základní škola. (1996). Praha: Fortuna.

Komunikační výchova. Dostupné z: http://komunikacnivychova.upol.cz/index.php

\section{Kontakt:}

Mgr. Milan Polák, Ph.D.

Katedra českého jazyka a literatury

Pedagogická fakulta Univerzity Palackého v Olomouci

Žižkovo nám. 5, 77140 Olomouc

E-mail:milan.polak@upol.cz 
Mgr. Milan Polák, Ph.D.

Po absolvování Pedagogické fakulty UP v Olomouci učil třináct let český jazyk, hudební a tělesnou výchovu na základní škole. V roce 1992 nastoupil na Katedru českého jazyka a literatury PdF UP v Olomouci jako odborný asistent. Věnuje se didaktice českého jazyka na základní a střední škole, zabývá se mimo jiné také syndromem vyhoření učitelů a teorií učebnic. Svou pozornost zaměřuje na nové trendy ve vyučování, zejména na integrované vyučování a využití projektové metody.

\section{Proč a jak učit filosofii na středních školách? -}

Filozofická fakulta UK nabízí učitelům zdarma e-knihu didaktických textů (tisková zpráva)

Antologie Proč a jak učit filosofii na středních školách?, která do českého prostředí uvádí texty ze současné německé didaktiky filosofie, je určena především středoškolským učitelům, zejména gymnaziálním vyučujícím filosofie či celého společenskovědního základu, oborovým didaktikům a studentům učitelství a filosofie.

Cílem vydání e-knihy je poskytnout didaktickou a metodickou oporu při středoškolské výuce filosofie tak, aby byly naplněny intence Rámcového vzdělávacího programu pro gymnázia, a zaplnit tak mezeru v odborné a metodické literatuře k tématu. Témata, která kniha rozpracovává, jsou např.: rozvíjení samostatného myšlení studentů; filosofické kompetence; metodické texty; myšlenkové experimenty; filosofické divadlo; metody pro práci s textem, diskusi a psaní; hodnocení filosofického myšlení.

Editorka v první části úvodní studie uvádí argumenty pro takové pojetí středoškolské výuky filosofie, jež se soustředí na rozvíjení samostatného myšlení studentů, a rozpracovává pro tento účel filosofické kompetence. Ve druhé části představuje základní koncepce německé didaktiky filosofie a zdůrazňuje převládající principy výuky vhodné i pro naše podmínky. Texty v samotné antologii jsou pak rozčleněny do tři částí: 1. teoretické texty představující hlavní koncepce výuky filosofie (E. Martens, A. Röschová, M. Tiedemann aj.), 2. metodické texty, soustředící se na vybrané metody, jež rozvíjejí filosofické myšlení (např. myšlenkové experimenty, filosofické divadlo, metody pro práci s textem, diskusi a psaní), a 3. rozsáhlý text k hodnocení filosofického myšlení, včetně návrhů hodnotících kritérií pro vybrané typy úloh (D. Schmidt, P. von Ruthendorf).

E-knihu (PDF) vydavatel poskytuje zdarma učitelům a didaktikům na základě registrace na webu jakucitfilosofii.ff.cuni.cz.

Odkazy:

Web a registrace: http://jakucitfilosofii.ff.cuni.cz/

Ukázka z e-knihy: http://jakucitfilosofii.ff.cuni.cz/ukazka/

Vydavatelství FF UK: http://www.ff.cuni.cz/fakulta/vydavatelstvi/

Kontaktní osoba:

Mgr. Ondřej Sýkora

E-mail: ondrej.sykora@ff.cuni.cz

Tel.: +420731439761 